\title{
A Frame Analysis of VR and AR News Using Semantic Network Method
}

\author{
Sang-Hee Kweon ${ }^{1}$, Se-Jin Kim² ${ }^{2}$ Myung-Bean ${ }^{3}$ and Song Xue-na $\mathrm{Li}^{4}$ \\ ${ }^{1}$ Professor, Department of Journalism and Mass Communication, \\ Sungkyunkwan University \\ ${ }^{2}$ Graduate School of Journalism and Mass Communication, Korea University \\ ${ }^{3}$ Adjunct Professor, Sungkyunkwan University \\ ${ }^{4}$ Graduate School of Journalism and Mass Communication, \\ Sungkyunkwan University \\ skeweon@skku.edu,oosejinoo@naver.com,makeitup@daum.net \\ 444814892@qq.com
}

\begin{abstract}
This study conducted an empirically analyses the evolution of the news coverage of the evolution of two technologies, Virtual Reality(VR) and Augmented Reality(AR), using the Frame Theory. The 'network' analysis is utilized that examines word choices, relationships between words, and overall logical structures created by the relationships in order to analyze the existence of news frames for each developmental stage (period) of Virtual Reality (VR) and Augmented Reality (AR) technologies. To this end, content analysis was conducted on VR and AR related 7,079 news pieces for the duration of five years (2012 to 2016). As a result, news about VR and AR displayed similar frames. The news about the two technologies placed their focus on the technical aspects from 2012 to 2014, while the focus was placed on the spheres of cultural life such as contents from 2015 to 2016. As such, the news during the initial developmental stage of VR and AR gradually started from technology-oriented reporting methods, then moved to the reporting methods focusing on cultural aspects related to the two technologies and their users.
\end{abstract}

Keywords: Virtual Reality, Augmented Reality, Frame, Semantic Network

\section{Introduction}

In recent years, along with Virtual Reality, Augmented Reality is also attracting attention. Virtual Reality (VR) allows to access the virtual world created by a computer program and to experience the senses such as vision and hearing as in the real world, while Augmented Reality (AR) presents a virtual object in the form of hologram to overlap an existing physical space. The timings of initial development of the two technologies - VR and AR - differ. VR is not a completely new technology. Studies with attempts to implement a virtual reality had been continuously conducted since 1960s. However, the prerequisite conditions for implementing a virtual reality did not exist. Then a new opportunity loomed as technologies such as computing power, communication speed, 3D sensing, and high-resolution display develop and with the declining cost of hardware devices. AR, on the other hand, was first used by Tom Caudell of Boeing in 1990. Since the mid-2000s, it began to incorporate AR technology in civil services. Sony Computer Entertainment in 2007 had launched the AR game <The Eye of Judgment>, and in 2009, it scored a great success with <Eye Love Pet>. As such, VR and AR are being

Received (July 5, 2017), Review Result (October 29, 2017), Accepted (January 19, 2018) 
used in various parts of society that we are living. For instance, they are utilized in various fields including entertainment (games, movies, theme parks), service businesses (advertising, retail/shopping, tourism, health), education, media, industrial (automotive, manufacturing, real estate, and construction) (Jeon, Han, and Jang, 2017).

\section{Theoretical background}

\subsection{Study on the News Frame (Frame Theory)}

The frame analysis in the present study is being conducted based on key words, subjects, the relationship between VR and AR technologies with social culture, and the direction of reporting that appear in news reporting process regarding VR and AR per period, in addition to Frame Theory. Gitlin (1980) defined 'frame' as "persistent patterns of cognition, interpretation, and presentation, of selection, emphasis, and exclusion." This means that the producers of the news they create specific topics and meanings according to the form of ownership, text, audience, and the form of the overall culture of a society. Thus, in the process of reporting the news on VR and AR, the press has a tendency of reporting with a specific view and frame. Further, according to the views of Tuchman (1978), the news is 'a window into the world.' That is, as the landscape outside of a window differs according to the structure and size of the window, the news explains and interprets issues through a specific frame. The news about VR and AR has been reported for a long period of time; it can be seen that each period has specific characteristics. Iyengar and Simon (1993) classified frames into episodic frames and thematic frames. An episodic frame, focusing on specific cases or examples, emphasizes personalization, dramatization, and conflicts, thereby describing issues as emotional; a thematic frame, on the contrary, refers to an interpretative reporting method that is based on professional knowledge and support that identify the issues' causes and consequences with in-depth background, context, and social structural characteristics. Therefore, the news on AR and VR and their structure can be divided into such two aspects. In other words, the two are tendencies that appear in the developmental process of AR and VR technologies.

\subsection{Research on Semantic Network Analysis and Centrality}

Semantic network analysis is a computer-based message analysis method that compensates the traditional content analysis method's shortcomings of not being able to rule out subjective interpretation of a researcher and its labor-intensiveness (Park \&Leydesdorff, 2004; Jang, 2001). In addition, there is an advantage that it can capture the dynamic meaning in the context of interacting relationships rather than the fixed property or concept of individual words (Kim, 2011). Furthermore, semantic network analysis can extract the hidden structural patterns in a message by focusing on where each word is located within the overall network or how the words identified in the semantic network are creating what type of structure, moving away from being based merely on the combination between each word. Looking at previous studies, the combination of semantic network analysis with big data technologies identifies the intended flow of meaning hidden in newspaper articles via the frequency of each word and relationships between them mainly appearing in the newspaper article. It also allows acquisition of new information based on existing messages. In this study, centrality analysis will be used to analyze the issue. Centrality analysis is to analyze the position and role of a particular keyword in the whole structure. Centrality means the measure that identifies 'relative importance' of nodes in social network. According to the method of calculation, centrality index can be divided into degree centrality, closeness centrality, eigenvector centrality, and betweenness centrality; each method is the measurement tool for analyzing the role of each node in the network. Therefore, through such semantic network analysis and centrality calculation, this study aims to identify the ways in which VR and AR are 
signified through media reports in our society so far and the flow of such signification. Specific research questions are as follows:

Research Question 1: What differences in importantly treated words in relation to VR and AR exist for each period?

Research Question 2: How the key words on VR and AR in the media structure semantic networks in each period?

Research Question 3: What are the words that play an important role in VR and AR semantic network in the media and how their characteristics appear?

\section{Research Methods}

\subsection{Analysis Subjects and Data Collection}

This study has collected data from media reports on VR and AR. Data collection was conducted through a news search on the nation's largest portal site, Naver. The extraction targets were comprehensive national daily newspapers. The selection of the newspapers included both conservative and liberal newspapers in order to maintain the proper balance. Moreover, the analysis period of this study is from January 1, 2012 to December 31, 2016. From the media reports for five years, articles related to VR and AR were collected in addition to other data related to the two keywords. The results are shown in [Table 1] below. As it is shown in [Table 1], from 2012 to 2016, the amount of collected articles on VR is a total of 3,668 pieces, while the amount of data is 76,326 pieces. For $\mathrm{AR}$, the collected amount for the five-year period is 3,411 pieces with the total amount of data as 40,158 pieces. Furthermore, [Figure 1] is a graph that illustrates the difference between Naver news data amount on VR and AR from 2012 to 2016. As depicted in [Figure 1], the data amount of VR was lower than AR in 2012 and 2013, while the data amount on VR had rapidly increased since 2014, which resulted in the amount of 25,507 pieces, twice the amount of data on AR in 2016.

Table 1. Number of Data Used for Analysis Per Year (Unit: Pieces)

\begin{tabular}{c|c|c|c|c}
\hline \multirow{2}{*}{ Year } & \multicolumn{2}{|c|}{ Virtual Reality (VR) } & \multicolumn{2}{c}{ Augmented Reality (VR) } \\
\cline { 2 - 5 } & $\begin{array}{c}\text { Amount } \\
\text { collected }\end{array}$ & Amount of data & $\begin{array}{c}\text { Amount } \\
\text { collected }\end{array}$ & Amount of data \\
\hline 2012 & 780 & 1545 & 701 & 2693 \\
\hline 2013 & 742 & 2086 & 666 & 2722 \\
\hline 2014 & 690 & 5875 & 704 & 3834 \\
\hline 2015 & 708 & 17467 & 686 & 7063 \\
\hline 2016 & 748 & 49353 & 654 & 23846 \\
\hline Sum & 3668 & 76326 & 3411 & 40158 \\
\hline
\end{tabular}




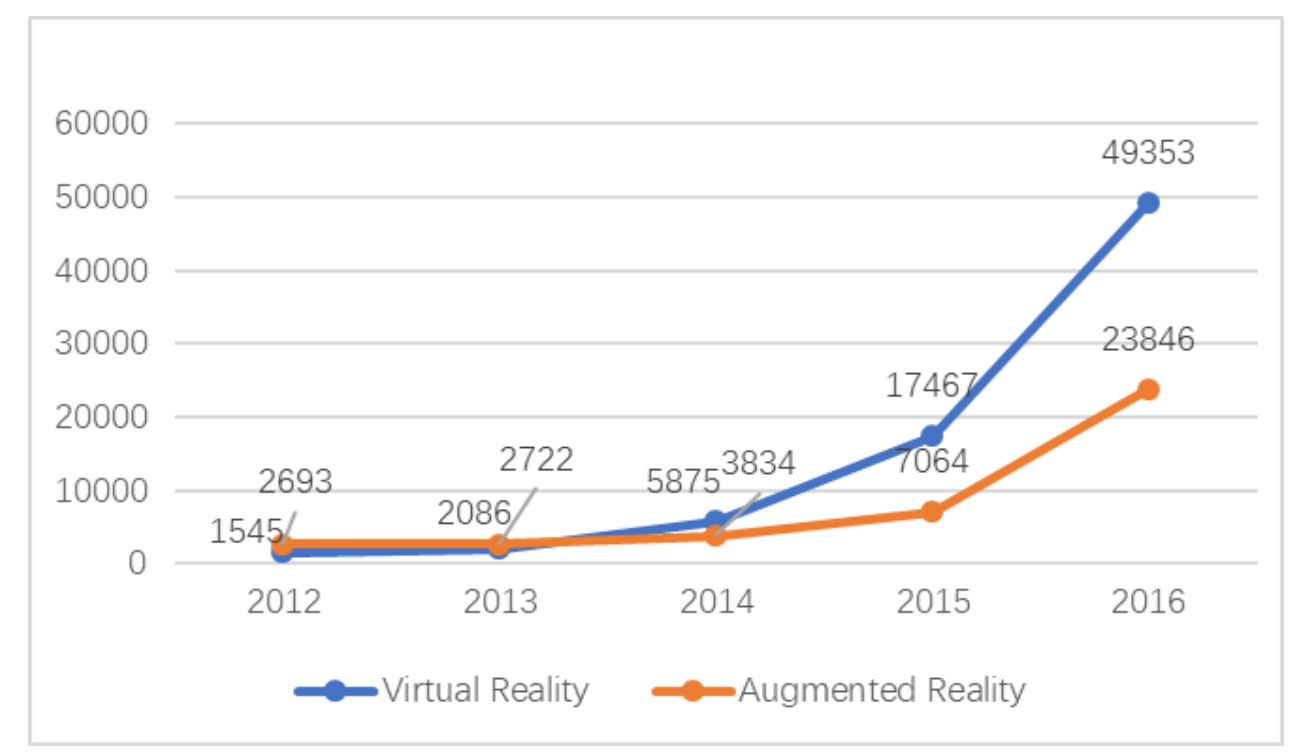

Figure 1. 2012-2016 Trends in Naver News on AR and VR

\subsection{Analysis Subjects and Data Collection}

From the collected data, the process of Textom text cleaning was conducted by elimination of meaningless propositions, word endings, and punctuation marks. Frequency matrix analysis was also conducted. The process provides the matrix data composed of occurrence frequency among the purified words. In addition, the matrix data may proceed to further analysis by using the network analysis programs such as NodeXL.

All of the processes were processed on Textom, the big data solution.

The extracted words were then analyzed using the network analysis program NodeXL that visualizes the data on the relationship between key words and other words. NodeXL is a social network analysis tool designed to collect, analyze, and visualize the different types of network data. NodeXL can collect data through a built-in importer from various online social media data such as Facebook, Twitter, Youtube, Flickr, and Wikipedia. Also, NodeXL can calculate key figures of social network analysis, including degree, centrality, density, and communitying coefficient, while it can express the networks subject to analysis in various visualization diagrams through its own internal visualization function.

To illustrate the details of the analysis method, the keyword, 'virtual reality,' collected based on the period of 2012 will be used. First, the collected data after collection, cleaning, and frequency matrix on Textom were loaded to NodeXL to progress with Graph Metrics calculation. Graph Metrics can describe the entire network or describe the subgroups or characteristics of a particular destination within one network. Next, in the auto fill columns in NodeXL's visual attributes menu, the values of edges and vertices were set to conduct mapping on visual characteristics. First of all, from edges columns, the entire edge weight was selected from the edge color, width, opacity, and visibility; specifically, the edge color was set at 128,128,128 in the color RGU 192,192,192. Edge width was set at 1.0 to 5.0, and the edge opacity and edge visibility were aimed at understanding and identifying the relationship between key words via the descending sort order. Therefore, the smallest value of the edge opacity and edge visibility was set to 50 . Additionally, in the vertices columns and vertex color, size, visibility, the entire vertex degree centrality was selected. All options relating to these were set to their default values. 


\section{Results}

\subsection{Comparative Analysis of Key Words on VR and AR by News Coverage Periods}

The first research question in this study is aimed at examining the differences in words with significance in the media in their coverage of VR and AR per period. To this end, the present study, as shown in the following [Table 2] and [Table 3], summarized the frequency order of key related words that appeared on the articles mentioning AR and VR.

First, the highly ranked words mentioned by Naver news per year, the frequency of the word, "virtual reality," increased from 1164 to 1798 times from 2012 to 2016. Looking at each year in detail, the high ranked key words of 2012 were 'VR (1164),' 'game (233)', 'technology (145),' 'global (130),' 'development (108),' and 'internet (105).' In 2013, 'VR (1177),' 'game (329),' 'oculus (206),' 'global (167),' 'internet (141),' and 'development (132)' - mainly technical terms occupied the top of the ranking. The word that was mentioned most frequently in 2014 was also 'VR (1676),' followed by 'oculus (261),' the user tool for VR contents. In the third place, 'headset (251)' was ranked a term that means the same. Additionally, 'Samsung electronics (210)' showed the frequency of over 200 times. In 2015, the frequency of 'VR' was 1881 times, followed by 'Samsung' with 318 times. Next, the words such as 'experience (193),' 'headset (176),' 'game (172),' 'launch (139),' and 'contents (127)' appeared. Finally, in 2016, 'VR' with the frequency of 1798 times was ranked as the number one, followed by 'experience (222),' 'AR (222),' 'technology (186),' and 'contents (158).'

Table 2. VR Related High-Ranked Keywords in Naver News Per Year

\begin{tabular}{|c|c|c|c|c|c|c|c|c|c|}
\hline \multicolumn{2}{|c|}{2012} & \multicolumn{2}{|c|}{2013} & \multicolumn{2}{|c|}{2014} & \multicolumn{2}{|c|}{2015} & \multicolumn{2}{|c|}{2016} \\
\hline word & $\begin{array}{l}\text { frequ } \\
\text { ency }\end{array}$ & word & $\begin{array}{l}\text { frequ } \\
\text { ency }\end{array}$ & word & $\begin{array}{l}\text { frequ } \\
\text { ency }\end{array}$ & word & $\begin{array}{l}\text { frequ } \\
\text { ency }\end{array}$ & word & $\begin{array}{l}\text { frequ } \\
\text { ency }\end{array}$ \\
\hline $\begin{array}{l}\text { virtual } \\
\text { reality }\end{array}$ & 1164 & $\begin{array}{l}\text { virtual } \\
\text { reality }\end{array}$ & 1177 & $\begin{array}{l}\text { virtual } \\
\text { reality }\end{array}$ & 1676 & $\begin{array}{l}\text { virtual } \\
\text { reality }\end{array}$ & 1881 & $\begin{array}{l}\text { virtual } \\
\text { reality }\end{array}$ & 1798 \\
\hline game & 233 & Game & 329 & Oculus & 261 & $\begin{array}{l}\text { Samsun } \\
\mathrm{g}\end{array}$ & 318 & $\begin{array}{l}\text { experie } \\
\text { nce }\end{array}$ & 222 \\
\hline $\begin{array}{l}\text { technol } \\
\text { ogy }\end{array}$ & 145 & Oculus & 206 & headset & 251 & $\begin{array}{l}\text { experie } \\
\text { nce }\end{array}$ & 193 & $\begin{array}{l}\text { augmen } \\
\text { ted } \\
\text { reality }\end{array}$ & 222 \\
\hline global & 130 & global & 167 & $\begin{array}{l}\text { Samsun } \\
\mathrm{g}\end{array}$ & 210 & headset & 176 & $\begin{array}{l}\text { technol } \\
\text { ogy }\end{array}$ & 186 \\
\hline $\begin{array}{l}\text { develop } \\
\text { ment }\end{array}$ & 108 & Internet & 141 & game & 146 & game & 172 & $\begin{array}{l}\text { content } \\
\mathrm{s}\end{array}$ & 158 \\
\hline Internet & 105 & $\begin{array}{l}\text { develop } \\
\text { ment }\end{array}$ & 132 & $\begin{array}{l}\text { technol } \\
\text { ogy }\end{array}$ & 141 & release & 139 & Korea & 136 \\
\hline $\begin{array}{l}\text { experie } \\
\text { nce }\end{array}$ & 93 & $\begin{array}{l}\text { experie } \\
\text { nce }\end{array}$ & 123 & $\begin{array}{l}\text { Facebo } \\
\text { ok }\end{array}$ & 134 & $\begin{array}{l}\text { content } \\
\mathrm{S}\end{array}$ & 127 & game & 135 \\
\hline movie & 71 & movie & 118 & global & 130 & $\begin{array}{l}\text { technol } \\
\text { ogy }\end{array}$ & 110 & global & 116 \\
\hline real & 65 & $\begin{array}{l}\text { technol } \\
\text { ogy }\end{array}$ & 107 & $\begin{array}{l}\text { experie } \\
\text { nce }\end{array}$ & 112 & Korea & 100 & service & 96 \\
\hline $\begin{array}{l}\text { smartph } \\
\text { one }\end{array}$ & 63 & Lift & 107 & USA & 101 & $\begin{array}{l}\text { develop } \\
\text { ment }\end{array}$ & 93 & hold & 96 \\
\hline $\begin{array}{l}\text { augmen } \\
\text { ted } \\
\text { reality }\end{array}$ & 59 & culture & 84 & $\begin{array}{l}\text { Samsun } \\
\mathrm{g}\end{array}$ & 100 & video & 92 & $\begin{array}{l}\text { develop } \\
\text { ment }\end{array}$ & 92 \\
\hline
\end{tabular}




\begin{tabular}{l|l|l|c|l|l|l|l|l|c}
\hline 3D & 57 & real & 62 & $\begin{array}{l}\text { develop } \\
\text { ment }\end{array}$ & 94 & Google & 91 & $\begin{array}{l}\text { industr } \\
\text { y }\end{array}$ & 91 \\
\hline use & 57 & $\begin{array}{l}\text { Smartp } \\
\text { hone }\end{array}$ & 61 & open & 92 & open & 84 & reporter & 90 \\
\hline $\begin{array}{l}\text { content } \\
\text { s }\end{array}$ & 57 & use & 61 & Release & 81 & global & 83 & Seoul & 89 \\
\hline uses & 55 & service & 59 & $\begin{array}{l}\text { take } \\
\text { over }\end{array}$ & 78 & reporter & 78 & market & 81 \\
\hline future & 53 & Use & 57 & device & 75 & Oculus & 78 & offer & 79 \\
\hline video & 51 & Korea & 55 & lift & 75 & Galaxy & 75 & video & 76 \\
\hline space & 50 & story & 54 & market & 67 & $\begin{array}{l}\text { smartph } \\
\text { one }\end{array}$ & 74 & G-Star & 76 \\
\hline Korea & 49 & $\begin{array}{l}\text { content } \\
\text { s }\end{array}$ & 53 & future & 61 & G-Star & 68 & future & 71 \\
\hline glasses & 48 & uses & 51 & content & 60 & market & 67 & uses & 68 \\
\hline
\end{tabular}

With the frequency ranking of the top words addressed in the media, an abstract picture of the ways the news reported VR and how agenda-setting changes. First, the frequency of the term 'VR' has been increasing every year for five years. In 2012, based on the fact that there were many technical words, it can be concluded that news coverages of VR were still being reported in the technical sphere. From 2013, however, words in the field of VR technology application such as game, experience, and contents started to appear, as the words related to the tools for using contents based on VR technology like Oculus or headset became the top ranked key words. Such a change means that VR technologies are becoming applicable in various sectors of our society. Additionally, with the increasing frequency of the term 'VR,' it can also be concluded that VR technology is gaining attention.

Next is [Table 3] that shows top-ranking related words related to AR appear in Naver news by year. Similar to VR previously mentioned, the frequency of the word 'AR' was the highest. From 2012 to 2014, in the top-ranked amongst the key words, the term 'technology' (2012: 185 times, 2013: 211 times, 2014: 243 times) was covered in the media reports was the second highest for three eyars. And in 2015 and 2016, in the second place was 'VR.' The top keywords in 2012, from the third-place, are 'app (157)', 'use (135)', 'smartphone (128)', and 'use (103)'; the top keywords in 2014 from the thirdplace start with 'VR (239),' followed by 'experience (130)', 'development (123)', 'game (116)', and 'service (110).' Moreover, again the term 'technology (282)' was ranked in the third place in 2015, followed by 'release (104)', 'contents (99)', and 'development (99).' Lastly, in 2016, 'game (640)' was ranked at the third place, followed by 'technology (245)' in the fourth, and 'smartphone (136)' and 'development (114).'

Table 3. AR Related High-Ranked Keywords in Naver News Per Year

\begin{tabular}{l|c|c|c|c|c|c|c|c|c}
\multicolumn{2}{c|}{2012} & \multicolumn{2}{|c|}{2013} & \multicolumn{2}{|c|}{2014} & \multicolumn{2}{|c|}{2015} \\
word & $\begin{array}{l}\text { frequ } \\
\text { ency }\end{array}$ & word & $\begin{array}{l}\text { frequ } \\
\text { ency }\end{array}$ & word & $\begin{array}{l}\text { frequ } \\
\text { ency }\end{array}$ & word & $\begin{array}{l}\text { frequ } \\
\text { ency }\end{array}$ & word & $\begin{array}{l}\text { frequ } \\
\text { ency }\end{array}$ \\
\hline $\begin{array}{l}\text { Augme } \\
\text { nted } \\
\text { Reality }\end{array}$ & 939 & $\begin{array}{l}\text { Augme } \\
\text { nted } \\
\text { Reality }\end{array}$ & 945 & $\begin{array}{l}\text { Augme } \\
\text { nted } \\
\text { Reality }\end{array}$ & 934 & $\begin{array}{l}\text { Augme } \\
\text { nted } \\
\text { Reality }\end{array}$ & 1055 & $\begin{array}{l}\text { Augme } \\
\text { nted } \\
\text { Reality }\end{array}$ & 1206 \\
\hline $\begin{array}{l}\text { Techno } \\
\text { logy }\end{array}$ & 185 & $\begin{array}{l}\text { Techno } \\
\text { logy }\end{array}$ & 211 & $\begin{array}{l}\text { Techno } \\
\text { logy }\end{array}$ & 243 & $\begin{array}{l}\text { virtual } \\
\text { reality }\end{array}$ & 742 & $\begin{array}{l}\text { virtual } \\
\text { reality }\end{array}$ & 640 \\
\hline App & 157 & $\begin{array}{l}\text { Smartp } \\
\text { hone }\end{array}$ & 126 & $\begin{array}{l}\text { virtual } \\
\text { reality }\end{array}$ & 239 & $\begin{array}{l}\text { Techno } \\
\text { logy }\end{array}$ & 282 & game & 245 \\
\hline Use & 135 & Uses & 114 & experie & 130 & Release & 104 & Techno & 183 \\
\hline
\end{tabular}




\begin{tabular}{|c|c|c|c|c|c|c|c|c|c|}
\hline & & & & nce & & & & $\log y$ & \\
\hline $\begin{array}{l}\text { Smartp } \\
\text { hone }\end{array}$ & 128 & service & 101 & $\begin{array}{l}\text { Develo } \\
\text { pment }\end{array}$ & 123 & $\begin{array}{l}\text { content } \\
\mathrm{s}\end{array}$ & 99 & $\begin{array}{l}\text { Smartp } \\
\text { hone }\end{array}$ & 136 \\
\hline uses & 103 & $\begin{array}{l}\text { Develo } \\
\text { pment }\end{array}$ & 94 & game & 116 & $\begin{array}{l}\text { Develo } \\
\text { pment }\end{array}$ & 99 & $\begin{array}{l}\text { Develo } \\
\text { pment }\end{array}$ & 114 \\
\hline service & 90 & $\begin{array}{l}\text { Informa } \\
\text { tion }\end{array}$ & 86 & service & 110 & Google & 92 & $\begin{array}{l}\text { domesti } \\
\text { c }\end{array}$ & 99 \\
\hline $\begin{array}{l}\text { Develo } \\
\text { pment }\end{array}$ & 83 & game & 80 & $\begin{array}{l}\text { Smartp } \\
\text { hone }\end{array}$ & 96 & service & 91 & $\begin{array}{l}\text { Pokém } \\
\text { on }\end{array}$ & 97 \\
\hline $\begin{array}{l}\text { Inform } \\
\text { ation }\end{array}$ & 81 & $\begin{array}{l}\text { Mobilit } \\
\mathrm{y}\end{array}$ & 79 & Uses & 86 & game & 89 & $\begin{array}{l}\text { content } \\
\mathrm{S}\end{array}$ & 82 \\
\hline glasses & 75 & Use & 74 & Google & 86 & $\begin{array}{l}\text { experie } \\
\text { nce }\end{array}$ & 84 & uses & 82 \\
\hline Google & 75 & $\begin{array}{l}\text { functio } \\
\mathrm{n}\end{array}$ & 71 & World & 79 & $\begin{array}{l}\text { Alone } \\
\text { Lens }\end{array}$ & 76 & reporter & 82 \\
\hline game & 72 & Release & 67 & smart & 74 & $\begin{array}{l}\text { Smartp } \\
\text { hone }\end{array}$ & 71 & Growth & 79 \\
\hline $\begin{array}{l}\text { functio } \\
n\end{array}$ & 70 & offer & 66 & Growth & 73 & avatar & 64 & Lenovo & 77 \\
\hline $\begin{array}{l}\text { Mobilit } \\
\mathrm{y}\end{array}$ & 70 & future & 60 & Base & 70 & uses & 62 & Release & 76 \\
\hline $\begin{array}{l}\text { content } \\
\mathrm{s}\end{array}$ & 67 & smart & 58 & $\begin{array}{l}\text { domesti } \\
\mathrm{c}\end{array}$ & 70 & image & 61 & Google & 74 \\
\hline offer & 60 & camera & 57 & $\begin{array}{l}\text { Wearab } \\
\text { le }\end{array}$ & 67 & offer & 60 & World & 72 \\
\hline email & 57 & Google & 57 & Use & 61 & Use & 59 & first & 69 \\
\hline video & 56 & base & 56 & video & 59 & base & 58 & future & 67 \\
\hline $\begin{array}{l}\text { Applic } \\
\text { ations }\end{array}$ & 56 & $\begin{array}{l}\text { experie } \\
\text { nce }\end{array}$ & 56 & Release & 59 & Navi & 56 & Seoul & 65 \\
\hline base & 54 & $\begin{array}{l}\text { content } \\
\mathrm{s}\end{array}$ & 55 & First & 59 & $\begin{array}{l}\text { Informa } \\
\text { tion }\end{array}$ & 56 & Pro & 63 \\
\hline
\end{tabular}

Abundant information can be inferenced through the changes in the top keywords and their rankings related to VR in Naver news for five years. Above all, AR has a lower number of reports compared to that of VR. Also, until recently, the tendency of reporting on the technological side is shown. Among the top ranked words on VR in 2016, AR was ranked as the number three. On the contrary, among the top ranked words related to AR, VR has positioned itself on the top from 2014 in the third, second, and second place. In addition, with the release of <Pokémon GO $>$ in U.S. in 2016, 'game' has suddenly jumped to the third place with the increased reporting related to contents in news reports on AR.

\subsection{Comparative Analysis of Centrality of VR and AR Key Words by Year}

With Graph Metrics calculation, the semantic networks related to VR in 2012 keywords shows 'VR' at the center. Also, the terms such as 'game', 'global', 'technology', and 'development' are linked to VR by thick lines, meaning that they constitute the center of the overall network. Still, such words are mostly related to technology. In 2013, two communities of centers appeared compared to 2012. 


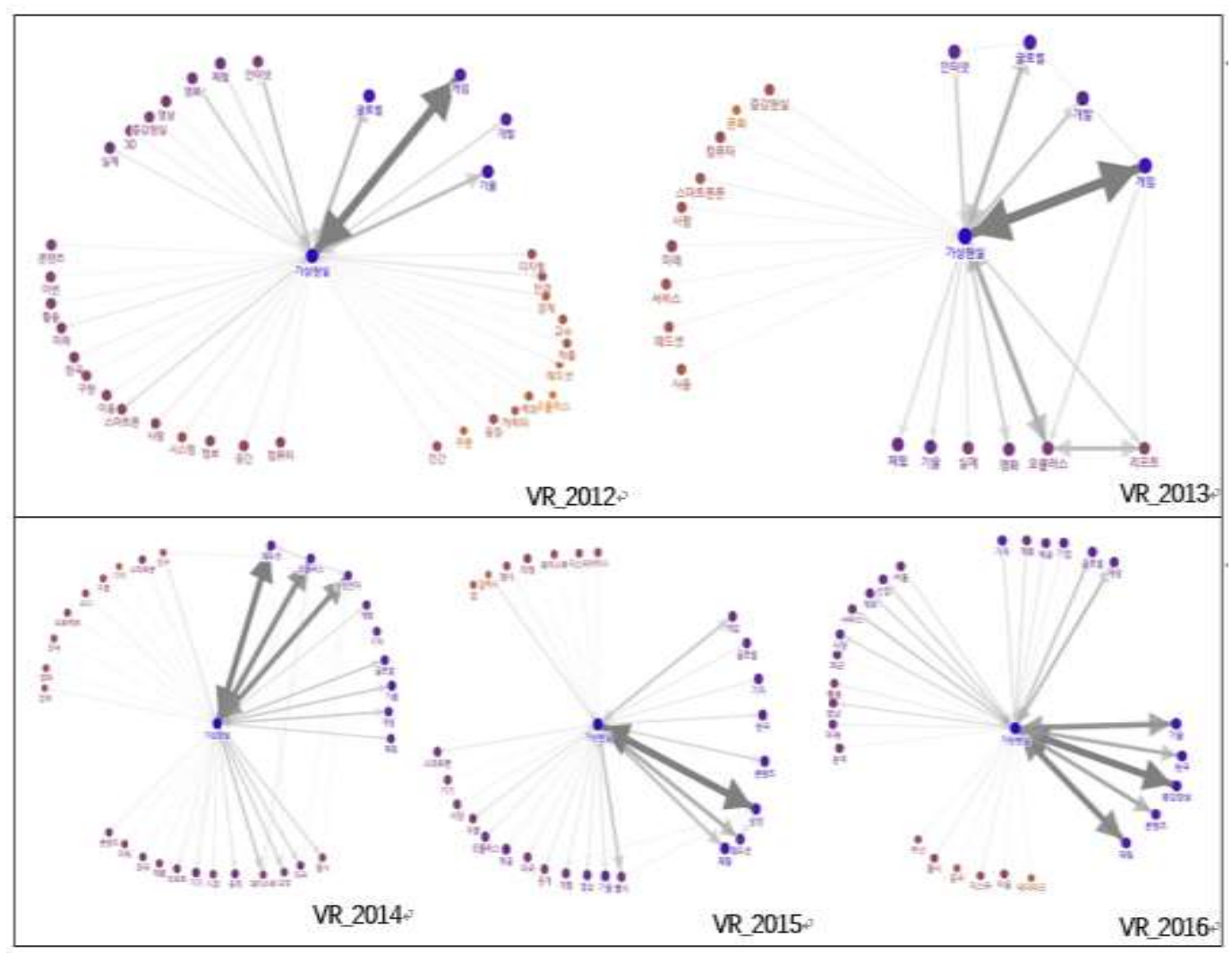

Figure 2. Analysis of Semantic Networks and Centrality of Keywords on VR Per Year

First, the community centering around VR is the largest community that linked to 'game', 'global', 'Oculus', and 'development' with think lines. Another community is centered around 'game', with 'development', 'global', 'lift', and 'Internet' at its lower ranks. The semantic networks of keywords related to VR in 2014 show 'VR', 'headset', 'Oculus', and 'Samsung Electronics' at the center. Among the communities, the community centered around VR is the largest, while a small number of words are connected to the community centered around the other three words, 'headset', 'Oculus', and 'Samsung Electronics'. In 2015, the keyword 'Samsung' has a high level of connectivity with VR, followed by 'headset', 'experience', 'game', and 'release'. Two communities can be found in the keywords semantic networks related to VR in 2015. The first is surely the largest community around VR, followed by the community of 'Samsung'. Yet, the words connected with the keywords of the community around 'Samsung' are not many with a low level of connectivity strength. The last is the semantic networks of keywords related to VR in 2016. The network consists of one community. At the center is VR, with 'AR', 'technology', 'experience', 'contents', 'Korea', 'game', and 'global' are located at the lower level. Among those words, 'AR', 'technology', and 'experience' have the thickest connecting lines. 


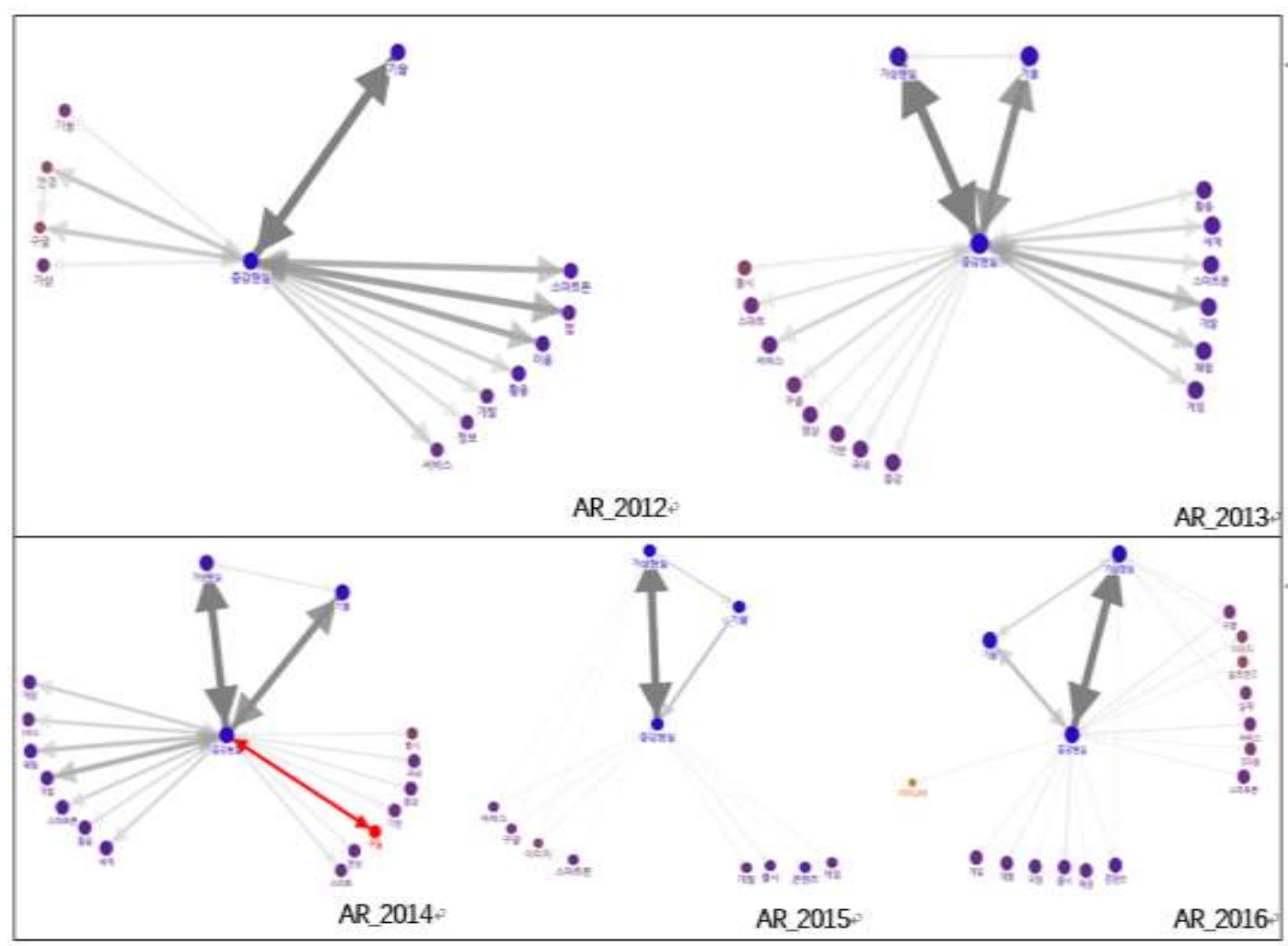

Figure 3. Analysis of Semantic Networks and Centrality of Keywordson AR Per Year

The semantic networks of keywords by AR is show that 'AR' located at the center in 2012. Also, the word 'technology' is connected with the centering word AR with a very thick line. The patterns appear in 2013 semantic networks have AR at the center with two other words, 'VR' and 'technology', connected with thick lines showing a high level of relevance. Although AR is the center of one large community, another small community has been created such as 'VR' and 'technology'.Looking at the semantic networks related to the keyword AR in 2014, it show the same fram with the 2013's. The keywords with a high level of connectivity to the keyword AR are 'VR' and also 'technology' in 2015. In 2015, the keywords semantic network on AR shows two communities. The first one is surely the largest community around AR, followed by one centering around the keyword 'VR'. Looking at the semantic networks related to the keyword AR in 2016, the words 'AR' and 'VR' are at the center of the network. With the Graph Metrics calculation, small communities or certain subjects were analyzed. Accordingly, in 2016, one large community was formed around AR. And as in 2015, another community was formed around the word 'VR'. Yet, such a community has a more complex pattern compared to the year before, and the word 'I-Navi' had an independent community.

And the 'Comparative Analysis of Centrality of Key Words Related to VR and AR by Year' has the same result with the semantic networks, so this part will be skipped.

\section{Conclusions}

This study empirically analyzed the evolution of the news coverage of the development of two technologies, Virtual Reality and Augmented Reality, by applying Frame Theory. The 'network' analysis was utilized that examines word choices, relationships between words, and overall logical structures created by the relationships in order to analyze the existence of news frames for each developmental stage (period) of Virtual Reality (VR) 
and Augmented Reality (AR) technologies. For this purpose, content analysis was conducted on VR and AR related 7,079 news pieces for the duration of five years (2012 to 2016).

The result of the study shows that, in 2012, the news about the two technologies placed their focus on the technical aspects from 2012 to 2014 as the VR and AR had gained newly established attention. Later, the focus moved to the spheres of cultural contents (entertainment), game, and experience using the technology, expanding the flow of the news to broader areas. More specifically, first, in terms of VR, technology-oriented stories were made by the news media in 2012. It can also be inferred that worldwide attention was given to the technologies. In addition, people were experiencing new games developed based on the VR technology, as shown in the results. From the news reports in 2013, games using the VR technology were being developed worldwide. The nodes ranked in the following rankings included the word 'technology', similar to that in 2012, it can be interpreted that the news frames were technology-oriented until 2013 in relation to VR. In 2014, as the VR technology progresses, the news frames were reflecting the cultural aspects derived from the interaction between users. In 2015, the experience of VR has received an increased attention. In experiencing VR, the user must wear a headset or Oculus. Accordingly, many news reports provided that, if a user wears such equipment for a prolonged period of time and experience VR, the user may suffer from dizziness like one would in using 3D, harming the user's body. In addition, with the increased centrality of the 'Samsung' node, it can be concluded that the development of such a technology has been led by Korean conglomerates. Moreover, it can be observed that the VR technology is being applied in various contents areas, not only in the sphere of gaming. And in 2016, first, 'technology' is being mentioned most often in news reports, meaning that the news is setting the agenda for decreasing negative reactions of a user's body after experiencing VR. Also, the number of news reports mentioning AR and VR together has increased. In other words, in order to develop the VR technology, it is combined with AR to create Mixed Reality, which is being increasingly covered in the news.

The detailed result of analysis in relation to AR is as follows. In 2012, the technical aspects of AR were covered extensively by the news media, followed by reports about smartphone, a tool that can often use AR. Considering highly ranked values, the agenda is being set that smartphone apps are the main tools for using AR as reported in the news. In the following year, 2013, technical aspects related to AR were still being mainly covered, in addition to the reports mentioning AR together with VR. Moreover, AR was also gaining much attention worldwide as VR, while being developed into games based on the technology. In 2014, there was not much development occurred. In 2015, the news media continuously covering AR together with VR, which stems from the fact that technological experts of the technologies argue that AR is a stepping stone toward evolving into VR. In addition, the new concept of Mixed Reality is becoming the agenda after being created based on the combination of VR and AR. Moreover, frames show that application of the VR technology has expanded beyond gaming to various industries such as movies, service businesses, and education. Also, it was shown that no significant change happened in 2016, as in 2015, and AR was still being used in various contents areas. Therefore, in the process of development of 5 years, the initial news reports about VR and AR showed the Thematic Coverage tendency, while the news reports in the latter part depict the Episodic Coverage tendency. In terms of the Thematic Coverage, news frames emphasize responsibilities in relation to the government, enterprises, and future technology development. Also, in the Thematic Coverage, frames heavily appear for user equipment sales, real-life experience, and application of such technology to program production.

The present study applied the semantic network analysis method that uncovers important meanings and implications by downsizing big data that allowed a more systematic analysis of public knowledge structure than the existing methods of semantic analysis. Furthermore, the results will be more apt for future strategic applications 
because the study allowed analysis of the connectivity and relationship between words within the visual and structural network connections.

Still, this study has limits. The present study divided the process of change in the knowledge and semantic structures related to VR and AR by year. However, according to the factors of period division (politics, policy, society, culture, technology, trend extrapolation), a different process of change can appear. Thus, in future studies, by dividing the periods based on various factors, it can be suggested to examine the process of change of news reports regarding VR and AR. Additionally, this study's subjects were comprehensive daily national newspapers. Future studies may have a medium that is most widely used by the audience as the subject of the study to create a research based on a vast quantity of data of audience agenda setting tendencies within the new media and to compare the data with comprehensive daily newspapers.

\section{Acknowledgments}

"This paper is a revised and expanded version of a paper entitled Analysis of News Frame Semantic Networks on Virtual Reality and Augmented Reality of the Media presented at HSST conference, Daejeon, Korea in December 21, 2018"

\section{References}

[1] S.-B. Kim, "The Korean Journal of International Relations", Korean Association of International Studied, vol. 51, no.4, (2011), pp.51-77.

[2] S.-H. Kweon, "Korean Journal of Communication \& Information", Korean Communication \& Information, vol. 30, no.- [2006], (2006), pp 35-87.

[3] S.-H. Kweon, "The Journal of study on the communicology", Korea Communication Association, vol.15, no.2, (2007), pp 33-63.

[4] H.-W. Park and L. Leydesdorff, "Journal of the Korean Data Analysis Society", Korean Data Analysis Society, vol.6, no.5, (2004), pp 1377-1387.

[5] H.-S. Lee, "Journal of Digital Convergence", The Korea Society of Digital Policy and Management, vol. 15, no.2, (2017), pp. 309-318.

[6] H.-Y. Jung, Korean Journal of Communication \& Information. Communication \& Information Society, vol.16 no.[2001], (2001), pp. 108-135.

[7] R. Entman, Journal of communication, OXFORD UNIVERSITY PRESS, vol. 43, no.4, (1993).

[8] E. Goffman, Cambridge, Mass: Harvard University Press, (1974).

[9] T. Gitlin, Berkeley: University California Press, (1980).

[10] S. Iyengar and A. Simon, Communication Research, vol. 20, no. 3, (1993), pp. 365-383.

[11] Tuchman.Gaye. New York : Free Press, xi, 244 p. : ill. ; 22 cm, (1978).
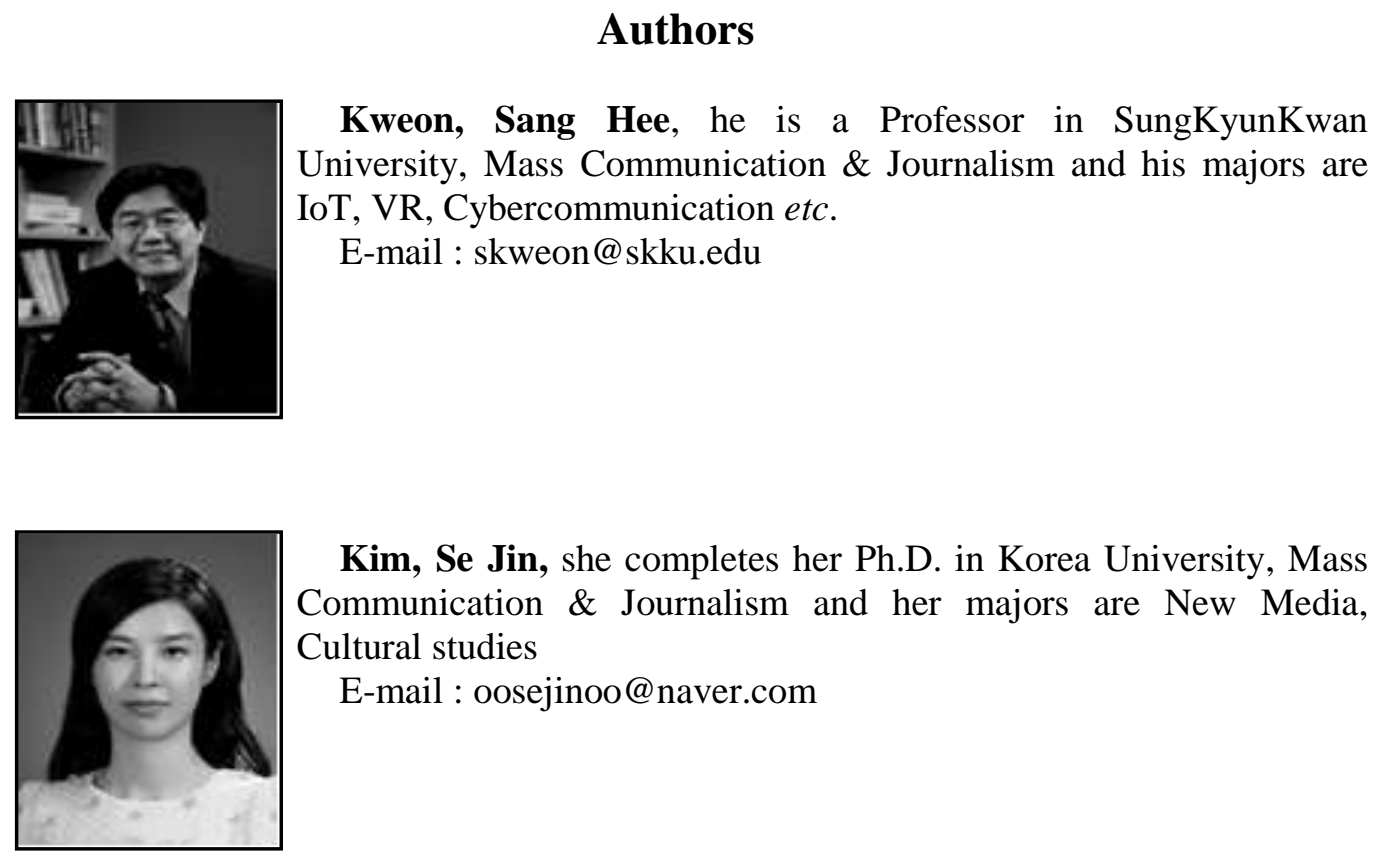

Kim, Se Jin, she completes her Ph.D. in Korea University, Mass Communication \& Journalism and her majors are New Media, Cultural studies

E-mail : oosejinoo@naver.com 


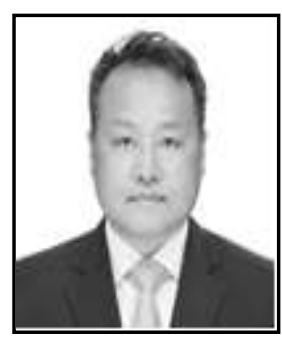

Song, Myung Bean, he is an Adjunct Professor in SungKyunKwan University, Mass Communication \& Journalism.

His majors are majors Multi-media, Big Data, Digital Extinction etc.

E-mail : makeitup@daum.net

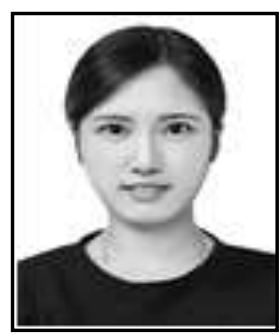

Li, Xuena, she received her Master in SungKyunKwan University, Mass Communication \& Journalism

Her majors are IoT, VR, Cybercommunication etc.

E-mail : 444814892@qq.com 